\title{
INTELLECTUAL CAPITAL AND FINANCIAL PERFORMANCE: BANKS' RISK AS THE MEDIATING VARIABLE
}

\author{
Anastasia Dian Cahyaningrum ${ }^{1}$, Apriani Dorkas Rambu Atahau ${ }^{2 *}$ \\ ${ }^{1}$ Graduates from Department of Management, Universitas Kristen Satya Wacana, Diponegoro 52-60, \\ Salatiga, 50711, Indonesia \\ ${ }^{2}$ Department of Management, Universitas Kristen Satya Wacana, Diponegoro 52-60, Salatiga, 50711, Indonesia \\ *Corresponding Author; Email: apriani@staff.uksw.edu
}

\begin{abstract}
This study seeks to investigate the impact of intellectual capital on banks' financial performance with banks' risks as the intervening variable. By using the purposive sampling technique, we selected 30 sample firms from publicly listed Indonesian banks in 2015-2017. This study generated the research data from banks' financial statements in those years. We then analyzed our data by using the Partial Least Square. The results demonstrate that banks' risks do not mediate the relationship between intellectual capital and banks' financial performance. Meanwhile, intellectual capital negatively affects operational risk and market risk. In addition, credit risk negatively affects banks' financial performance, and liquidity risk negatively affects banks' financial performance. Lastly, intellectual capital does not affect banks' financial performance.
\end{abstract}

Keywords: Non-performing loans; loan to deposit ratio; net interest margin; operating expense ratio; return on asset.

\section{Introduction}

As financial institutions, banks collect funds from the public, especially in the form of savings, and redistribute the funds to the public through credits or other activities that enhance the public's quality of life. Banks in Indonesia consist of state-owned, private, and foreign banks. The existence and activities of the bank industry determine countries' development levels. Financial performance is crucial to indicate banks' overall performance (Kansil, Murni, \& Tulung, 2017). Jumingan (2014) suggests that banks' financial performance reflects banks' performance in generating and distributing funds in a certain period.

Banks' financial statements inform banks' financial performance. Profitable firms are the consequences of firms' efficient activities in generating profits (Prahesti \& Abundanti, 2015). However, financial performance is less effective in assessing firms' overall performance. In this respect, financial statements should reveal firms' expected benefit. According to Herdyanto and Nasir (2013), the added values in financial statements are for example discoveries, innovation, human resource development, knowledge, and good customer relationship or commonly known as intellectual capital.

Firms undergo fundamental changes from laborbased business to knowledge-based business. Firms rely on knowledge to enhance their performance or commonly known as intellectual capital. Effective intellectual capital tends to reveal that firms utilize their intellectual capital effectively. In this respect, firms with better intellectual capital are more likely to disclose more on intellectual capital.

Disclosure that is more extensive is likely to increase stakeholders' trust in firms. Further, higher intellectual capital will reduce firms' risks. Brunold and Durst (2012) suggest that firms need to manage their intellectual capital cautiously. Stakeholders should focus on risks that involve intellectual capital. Generating public trust involves such a high risk that banks need to comply with risk-related regulations.

According to Mustofa and Haryanto (2014), banks only focus on the upside of their businesses (profit and growth achievement) and not on the downside of the business (risks) in evaluating their performance. The upside-focused evaluation is arguably bias and not oriented toward the achievement of long-term objectives. Consequently, banks should assess their performance comprehensively by including both the upside and downside aspects of the business. Stulz (2013) proposes "the first principle" of risk management that emphasizes firms' comparative advantage in managing their risks and the use of integrated risk management to avoid poor results. Financial institutions specifically implement this principle to support the financial system. Besides, better risk management helps firms make better riskrelated decisions and not only reduce risks (Stulz, 2015; Robiyanto, 2017).

In the banking industry, risk is a factor that affects financial performance each bank will face various risks 
in achieving profit. Higher risks imply that banks should take their capital risk carefully. Risks in the banking industry are due to the fund collection and distribution in the form of investments, credit allocation, the investment of securities, and other investment opportunities. Risks largely depend on the managerial ability to manage risks.

Regarding the relationship between intellectual capital, banks' risks, and banks' financial performance, Silaban (2018) has investigated the relationship between banks' risks and banks' financial performance of publicly listed national bank and uses the good corporate governance variable as the moderating variable. Thus, different from previous studies, this study uses the banks' risk as the intervening variable. As a service industry, the banking industry heavily relies on intellectual capital in its activities. Banks also incur a great amount of employee costs that reflect the crucial role of intellectual capital (Andriana, 2014). Meanwhile, we use banks' risks as the intervening variable because no other studies, to our best knowledge, have done it before.

The following are our research problems. First, how does intellectual capital affect credit risk, liquidity risk, market risk, and operational risk? Second, how does credit risk affect banks' financial performance? Third, how does liquidity risk affect banks' financial performance? Fourth, how does market risk affect banks' financial performance? Fifth, how does operational risk affect banks' financial performance? Sixth, how does intellectual capital affect banks' financial performance? This study aims to test the impact of intellectual capital on banks' financial performance with banks' risk as the intervening variable in publicly listed banks for the 2015-2017 periods. More specifically, we seek to analyze the direct and indirect effects of intellectual capital on banks' risks and banks' financial performance. The study contributes by informing banks when they make decisions to improve their performance and by advising the public on factors that affect banks' performance.

\section{The Effect of Intellectual Capital on Operational Risk}

Intellectual capital plays a crucial role in cost efficiency. Banks' capabilities and knowledge will greatly affect their efficiency. Banks can use their intellectual capital to enhance their efficiency (Gama $\&$ Mitariani, 2014). Various scopes of intellectual capital will help banks to operate most efficiently by minimizing costs and generating high revenues at the same time. Thus, higher intellectual capital capability enables banks to manage their costs more efficiently (van der Meer-Kooistra \& Zijlstra, 2001). In particular, higher intellectual capital will reduce BOPO and eventually will increase banks' efficiency. Rustiarini and Gama (2012) observe that IC negatively affect BOPO. Consequently, we propose the following first hypothesis:

$H_{l}$ : Intellectual Capital negatively affects operational risk.

\section{The Effect of Intellectual Capital on Liquidity Risk}

The intellectual capital components that consist of employees' experience and knowledge, banks' relationship with their customers, and banks' organizational or managerial condition likely affect liquidity risk (Joshi, Cahill, Sidhu, \& Kahil, 2013). Banks that distribute more credits to their customers will generate more credit revenue. However, these banks need to focus on increased liquidity risk. In this respect, banks can mitigate or at least maintain their liquidity risk by relying on their employees' knowledge or experience (Mondal \& Gosh, 2012). Higher intellectual capital will reduce liquidity risk because banks that manage their intellectual capital effectively arguably manage to minimize their liquidity risk. Conversely, higher LDR reduces banks' liquidity and increases banks' liquidity risk (Yalama, 2013).

Aprilina (2013) examines the impact of intellectual capital on liquidity risk by elaborating on each intellectual capital component partially and demonstrates that VACA (STVA) exhibits a significantly negative (positive) influence on LDR. However, VAHU does not significantly affect LDR. Based on these arguments, we propose the following hypothesis: $\mathrm{H}_{2}$ : Intellectual capital negatively affects liquidity risk.

\section{The Effect of Intellectual Capital on Market Risk}

Banks' NIM is heavily affected by several factors, either internal or external. External factors are macroeconomic conditions such as inflation and foreign exchange rate. External factors significantly affect banks' intellectual capital (Nijhawan \& Taylor, 2005). Higher intellectual capital values indicate that banks manage to utilize their value creation potentials effectively. Firms that heavily rely on intellectual capital emphasize the importance of knowledge in managing their firms and improving their performance (Gama \& Mitariani, 2014). Likewise, higher intellectual capital will reduce market risk because better intellectual capital management enables banks to mitigate their market risk. Elfiswandi, Pratiwi, and 
Melmusi (2019) find that the VACA, VAHU and STVA variables simultaneously affect NIM. Thus, we propose the following hypothesis:

$H_{3}$ : Intellectual capital negatively affects market risk.

\section{The Effect of Intellectual Capital on Credit Risk}

Besides market conditions, the intellectual capital components that consist of employees' experience and knowledge, organizational or managerial culture, banks' relationship with their customers likely affect credit risk (Yalama, 2013). Banks that provide more credits to their customers likely have a greater risk of non-performing loans. In this respect, higher intellectual capital will reduce credit risk (Taswan, 2015). Banks that manage their intellectual capital effectively will mitigate their credit risk. Aprilina (2013) documents that VAHU negatively affects NPL, while VACA and STVA positively affect NPL. Based on these arguments, the following is our fourth hypothesis:

$H_{4}$ : Intellectual capital negatively affects credit risk.

\section{The Effect of Operational Risk on Banks' Financial Performance}

Operational risk or operating expense ratio (BOPO) is commonly labeled as efficiency ratio. Firms with low BOPO have low operating expenses relative to their operating revenues. Well-performing banks likely increase public trust to deposit funds that will further improve banks' performance (Pinasti \& Mustikawati, 2018). Lower BOPO implies that banks are more efficient in incurring their expenses (Purnomo, Sriwidodo, \& Wibowo, 2018).

Mismiwati (2016) and Purnomo et al. (2018) demonstrate that BOPO, as a proxy of operational risk, negatively affects banks' financial performance. Thus, we propose the following hypothesis:

$H_{5}$ : Operational risk negatively affects banks' financial performance.

\section{The Effect of Liquidity Risk on Banks' Financial Performance}

Liquidity risk (with LDR as the proxy) reflects banks' ability to repay their depositors' funds withdrawals by relying on their credits as the liquidity sources. In other words, liquidity risk refers to the extent credit allocations to banks' credit customers' balance the obligations to fulfill depositors' demands to withdraw their funds. Lower LDR indicates that banks are less effective in allocating credits and in generating profits (Pinasti \& Mustikawati, 2018). Haryati and Widyarti (2016), Mismiwati (2016), and Harun (2016) show that LDR as the proxy of LDR positively affects banks' financial performance. Based on these arguments, we propose the following hypothesis:

$H_{6}$ : Liquidity risk positively affects banks' financial performance.

\section{The Effect of Market Risk on Banks' Financial Performance}

Increased banks' profits are likely affected by income revenue and the quality of their productive assets. In this respect, higher NIM will increase interest revenue relative to their productive assets and eventually their financial performance According to Pinasti and Mustikawati (2018), NIM reflects market risk that emerges due to detrimental changes in market variables. Higher NIM will increase banks' profits, and lower NIM will increase market risk. Thus, we propose the following hypothesis:

$H_{7}$ : Market risk positively affects banks' financial performance.

\section{The Effect of Credit Risk on Banks' Financial Performance}

Increased risk due to non-performing loans likely reduces banks' profits or financial performance. Besides, higher credit risk worsens credit quality, increases non-performing credits, and eventually exacerbates banks' problems (Harun, 2016). Higher non-performing loans delay banks' revenues and reduce banks' profits (Pinasti \& Mustikawati, 2018). Harun (2016) find that NPL as the proxy of credit risk negatively affects banks' financial performance. Based on these studies, we propose the following hypothesis: $H_{8}$ : Credit risk negatively affects banks' financial performance.

\section{The Effect of Intellectual Capital on Banks' Financial Performance}

Higher ROA reflects firms' better ability to utilize both of their physical and non-physical (intellectual) assets to generate profits efficiently (Kuspinta \& Husaini, 2018). Higher intellectual capital will affect firms' profit. Firms that effectively manage the three intellectual capital components manage their overall assets better. In this respect, banks' managerial ability to enhance their intellectual capital will improve their financial performance. Specifically, higher intellectual capital will facilitate banks to enhance their financial 
performance. Thus, better intellectual capital management will create more benefit and eventually improve performance (Faza \& Hidayah, 2014). Simarmata and Subowo (2016), Nurhayati (2017), and Rachmawati (2012) show that intellectual capital positively affects banks' financial performance. Thus, we propose the following hypothesis:

$H_{9}$ : Intellectual capital positively affects banks' financial performance.

\section{The Effect of Intellectual Capital on Banks' Financial Performance with Banks' Risks as the Intervening Variable}

As suggested by Putriani (2010), higher intellectual capital as the intangible assets and lower risk will improve banks' future operational accuracy. Meanwhile, lower risk tends to improve banks' financial performance. This argument is in line with Attar et al. (2014) who propose that banks' risks simultaneously affect their financial performance. Consequently, higher intellectual capital improves performance accuracy and reduces banks' risks that will eventually increase banks' financial performance. Thus, our last hypothesis will be:

$H_{10}$ : Intellectual capital positively affects banks' financial performance with banks' risks as the intervening variable.

\section{Research Method}

This study employed quantitative data. According to Sugiyono (2013), the quantitative method seeks to test hypotheses based on positivism approach to investigate a certain population with quantitative data. The data was annual reports of commercial banks listed on the Indonesian Stock Exchange (IDX) in 2015-2017. This study aims to test the causal relationships between the research variables, namely intellectual capital, banks' risks, and banks' financial performance.

Our population was 43 commercial banks that were listed on IDX per July 2018, excluding sharia banks. We selected the sample by using the purposive sampling technique with the sole criteria of data availability for all ratios as the proxies of each variable. Consequently, we had to leave out 13 banks due to the data availability issue and retain 30 banks as the final sample firms. We used secondary data of the annual reports of 30 publicly listed commercial banks in 2015-2017. The study generated the data from the websites of IDX (www.idx.com.id) and FSA (Financial Services Authority) (www.ojk.go. id). We used the Partial Least Square (PLS) by relying on SmartPLS software. As a non-parametric statistical analysis, PLS does not require normally distributed data. Also, PLS does not need to have a large sample number because it is variance-based. Specifically, PLS

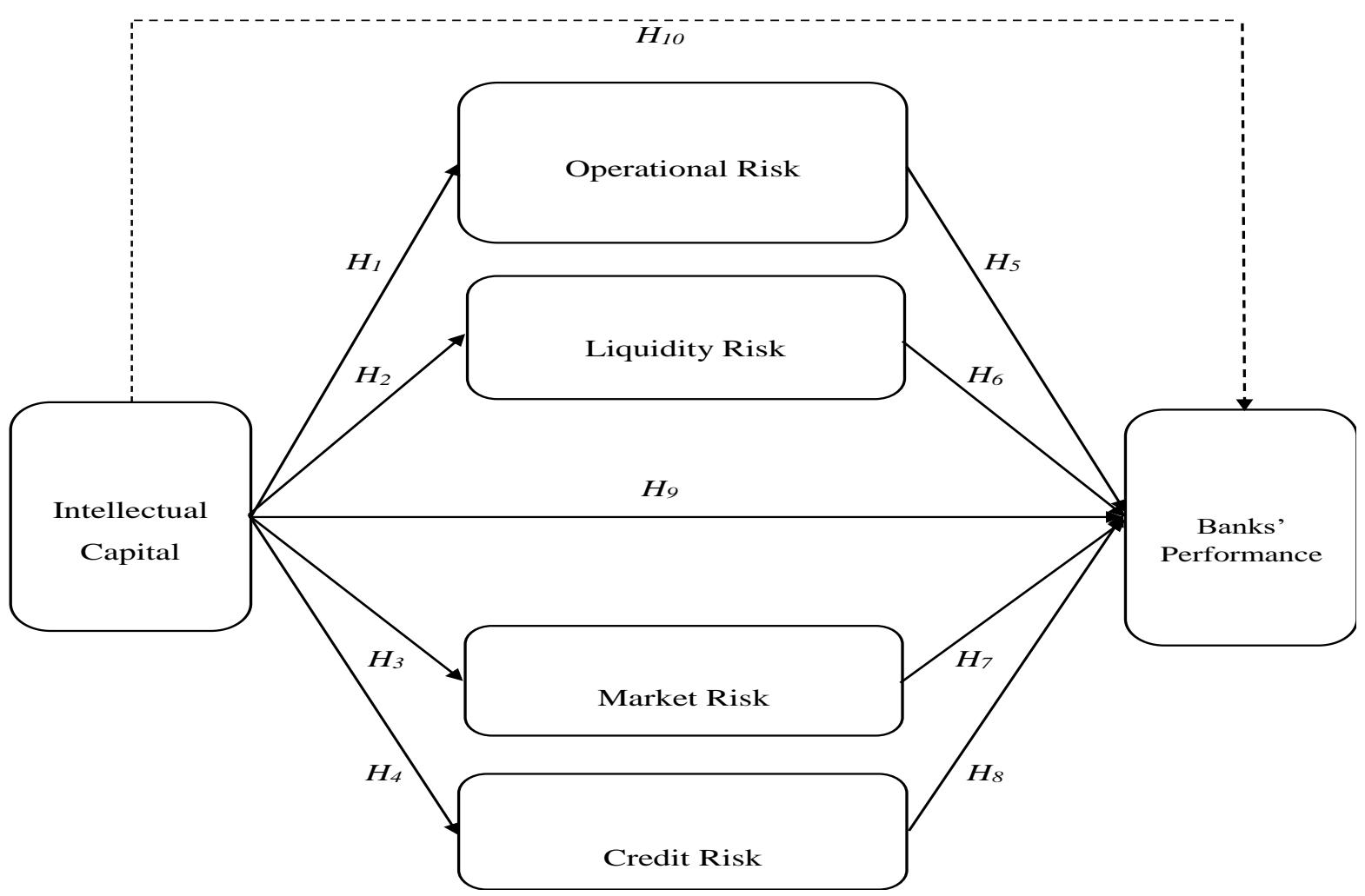

Figure 1. The conceptual research framework 
can use 30 to 100 sample observations. We considered that the PLS characteristic that referred to variance values fit with our research (Sholihin \& Ratmono, 2013).

The independent variable of this study is intellectual capital with banks' risks (credit risk, liquidity risk, market risk, and operational risk) as the intervening variable and banks' financial performance as the dependent variable. The definition and measurement of research variables is provided in Attachment 1.

\section{Result}

\section{Descriptive Statistics}

Descriptive statistics inform the characteristics of our sample observations. More specifically, the analysis provides general description of data characteristics through several parameters, such as mean, minimum, and maximum values. The discussion starts with the independent variable, namely intellectual capital and banks' risks (NPL, NIM, BOPO, and LDR). Next, we discuss banks' financial performance (ROA) as the dependent variable. Table 1 shows the descriptive statistics.

Table 1

Descriptive Statistics

\begin{tabular}{lrrr}
\hline Variable & \multicolumn{1}{c}{ Mean } & \multicolumn{1}{c}{ Min } & \multicolumn{1}{c}{ Max } \\
\hline IC & 5.88 & 0 & 17 \\
NPL (\%) & 1.86 & 0 & 6.37 \\
NIM $(\%)$ & 5.22 & 0.93 & 12 \\
BOPO (\%) & 92.21 & 58.6 & 235.2 \\
LDR (\%) & 83.12 & 50.61 & 108.78 \\
ROA (\%) & 0.89 & -11.15 & 4.19 \\
\hline
\end{tabular}

We measured intellectual capital with the VAIC method that adds the three main elements within organizations, namely human capital, structural capital, and customer capital. PT Bank MNC Internasional Tbk. (2017) and PT Bank Nusantara Parahyangan Tbk. (2017) exhibit the minimum intellectual capital value (zero). Meanwhile, PT Bank of India Indonesia Tbk. (2015) has the highest intellectual capital value (17). The figure implies that in 2015, PT Bank of India Indonesia Tbk. managed to utilize its intangible assets optimally to generate benefits in the form of competitive advantage. Banks' risks were measured with credit risk (NPL), market risk (NIM), operational risk (operating expense ratio), and liquidity risk (LDR). PT Bank National Nobu Tbk. $(2015,2016)$ has the lowest NPL (zero) while PT Bank Bukopin Tbk. (2017) has the highest NPL value (6.37), implying that in 2017 PT Bank Bukopin Tbk. had the highest non-performing loans than other banks. Further, PT Bank Jtrust Indonesia Tbk. (2015) has the lowest NIM (0.93) and PT Bank Tabungan Pensiunan Nasional Tbk. (2016) has the highest NIM value (12), indicating that in 2016 PT Bank Tabungan Pensiunan Nasional Tbk. managed to increase its interest revenue on its productive assets. The lowest BOPO is 58.6 (PT Bank Central Asia Tbk., 2017), suggesting that in 2017 the bank improved its managerial ability in utilizing its resources more efficiently. However, PT Bank of India Internasional Tbk. (2017) has the highest BOPO (235.2). For LDR, PT Bank Capital Indonesia Tbk. (2017) has the lowest value (50.61), while the highest value is 108.58 (PT Bank Tabungan Negara (Persero) Tbk. 2015). However, the figure still falls below the threshold

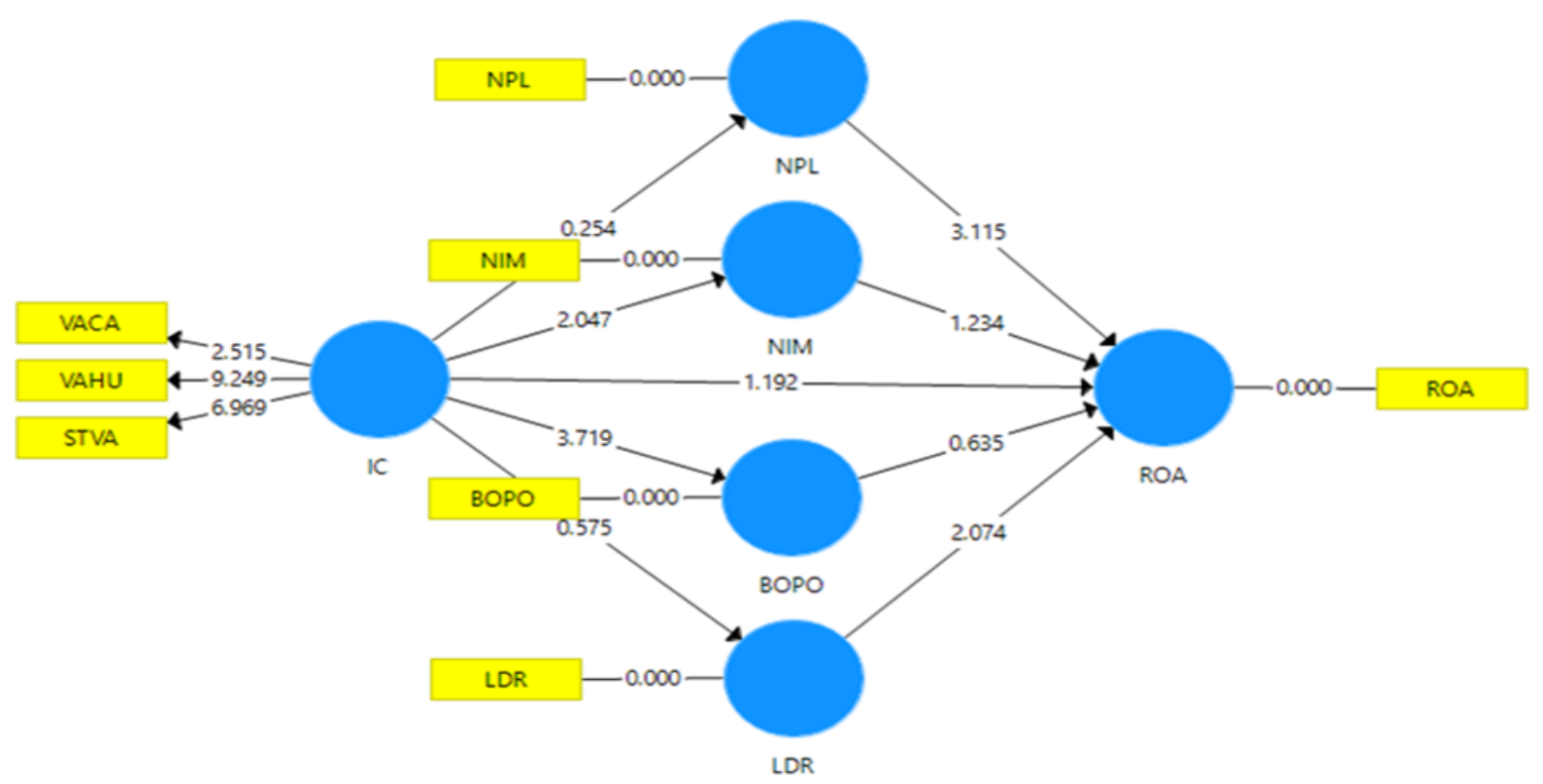

Figure 2. Output bootstrapping 
(11\%), implying that the bank can still be considered healthy.

We measured banks' financial performance with ROA. The minimum value of ROA is - 11.15 (PT Bank of India Indonesia Tbk., 2016) while the maximum value is 4.19 (PT Bank Rakyat Indonesia (Persero) Tbk., 2015), indicating that in 2015 PT Bank Rakyat Indonesia (Persero) Tbk. was more effective than other banks in managing its assets to generate higher profits.

\section{Test of the Structural Model}

The following figure illustrates the results of the bootstrapping test with a significance value of 5\%.

\section{The Multicollinearity Test}

The multicollinearity test aims to investigate the presence of the correlations between the independent variables (Ghozali, 2011). Multicollinearity exists when the VIF value exceeds ten. The table below informs that no independent variable has VIF more than ten, implying that no multicollinearity exists.

Table 2

The Multicollinearity Test

\begin{tabular}{cc}
\hline Variable & VIF \\
\hline BOPO & 1.000 \\
LDR & 1.000 \\
NIM & 1.000 \\
NPL & 1.000 \\
STVA & 1.508 \\
VACA & 1.115 \\
VAHU & 1.527 \\
\hline
\end{tabular}

\section{The R-Square Value}

The $R$-square value is the goodness-of-fit model for each latent variable, namely the dependent variable as the predictive power of the structural model or inner model. The test is necessary to evaluate the inner model. The following is the table for the $R$-square value.

Table 3

The $R$-Square Value

\begin{tabular}{cc}
\hline Variable & $R$ Square \\
\hline BOPO & 0.156 \\
LDR & 0.004 \\
NIM & 0.047 \\
NPL & 0.002 \\
ROA & 0.337 \\
\hline
\end{tabular}

The $R$-square value of $\mathrm{BOPO}$ is 0.156 , implying that intellectual capital explains 0.156 or $15.6 \%$ of the total variance of $\mathrm{BOPO}$, while the rest is explained by other variables not included in this research. Next, the $R$-square value of LDR is 0.004 , suggesting that intellectual capital only explains 0.004 or $0.4 \%$ of LDR's variance while other variables explain the rest. Further, the $R$-square value of NIM is $0.047 \%$. Thus, intellectual capital explains 0.047 or $4.7 \%$ of the variance of NIM, while the rest is explained by other variables outside the model. The $R$-square value of NPL is 0.002 , indicating that intellectual capital explains 0.002 or $0.2 \%$ of the total variance of NPL, and other variables explain the rest. Lastly, the $R$ square value of ROA is 0.337 , implying that 0.337 or $33.7 \%$ of the total variance of ROA is explained by intellectual capital while the rest is explained by other variables not included in this model.

\section{Significance Test}

The t-statistics values of each latent variable demonstrate the significance of the effect of intellectual capital on banks' risks (NPL, NIM, LDR, and BOPO) and financial performance, and the impact of banks' risks on banks' financial performance. The following Table 4 displays the results of the bootstrapping test.

We selected the significance value of 5\% in testing the hypotheses and compared it with the $p$ value. We also analyze the direction of the effect from the estimation of the value of the original sample or the parameter coefficient. The result is statistically significant if the $t$-statistics is greater than 1.96 and $p$-value is less than 0.05 or $5 \%$.

Meanwhile, the importance-performance analysis (IPMA) seeks to identify the performance of each independent variable and to identify variables with relatively high importance values to the targeted construct or dependent variable (Hair Jr., Hult, Ringle, \& Sarstedt, 2017). Table 6 suggests that intellectual capital that consists of VACA, VAHU, and STVA exhibits the highest positive importance of 92.395 and negative while NPL has the highest negative importance of -0.598 on banks' performance. Intellectual capital also has the highest performance value of 77.005. The findings indicate that intellectual capital has higher performance and importance values on banks' financial performance than other variables.

The following section discusses the results of the hypothesis testing and their interpretations. The results show that the $t$-statistics of the impact of intellectual capital on BOPO is 3.719>1.96 (p-value $0.000<0.05$ ) with the original sample value of -0.395 , suggesting 
Table 4

Significance Test

\begin{tabular}{lcccc}
\hline & $\begin{array}{c}\text { Original } \\
\text { Sample }\end{array}$ & T Statistics & P-Values & Explanation \\
\hline BOPO $\rightarrow$ ROA & -0.098 & 0.635 & 0.526 & rejected \\
IC $\rightarrow$ BOPO & -0.395 & 3.719 & 0.000 & supported \\
IC $\rightarrow$ LDR & 0.063 & 0.575 & 0.565 & rejected \\
IC $\rightarrow$ NIM & -0.217 & 2.047 & 0.041 & supported \\
IC $\rightarrow$ NPL & -0.043 & 0.254 & 0.800 & rejected \\
IC $\rightarrow$ ROA & 0.191 & 1.192 & 0.234 & rejected \\
LDR $\rightarrow$ ROA & 0.306 & 2.074 & 0.039 & supported \\
$\mathrm{NIM} \rightarrow$ ROA & 0.239 & 1.234 & 0.218 & rejected \\
$\mathrm{NPL} \rightarrow$ ROA & -0.393 & 3.115 & 0.002 & supported \\
\hline
\end{tabular}

Table 5

Total Indirect Effects

\begin{tabular}{|c|c|c|c|c|c|}
\hline & & Original sample & T Statistic & P-Values & Explanation \\
\hline BOPO & $>\mathrm{ROA}$ & & & & \\
\hline IC & $>\mathrm{BOPO}$ & & & & \\
\hline IC & $>\quad \mathrm{LDR}$ & & & & \\
\hline IC & $>\mathrm{NIM}$ & & & & \\
\hline IC & $>\mathrm{NPL}$ & & & & \\
\hline IC & $>\mathrm{ROA}$ & 0.023 & 0.228 & 0.819 & rejected \\
\hline LDR & $>\mathrm{ROA}$ & & & & \\
\hline NIM & $>\mathrm{ROA}$ & & & & \\
\hline NPL & $>\mathrm{ROA}$ & & & & \\
\hline
\end{tabular}

that intellectual capital negatively affects operational risk. Thus, the first hypothesis of intellectual capital negatively affects operational risk is empirically supported. Our empirical test does not empirically support the second hypothesis, as indicated by the $t$-statistics of $0.575<1.96$ ( $p$-value $0.565>0.05)$ and the original sample value of 0.063 . The findings show that there is no significant impact of intellectual capital on liquidity risk. Thus, the second hypothesis of intellectual capital negatively affects liquidity risk is rejected.

Table 6

Importance-Performance Matrix Analysis (IPMA)

\begin{tabular}{lcc}
\hline & Importance & Performance \\
\hline BOPO & -0.005 & 38.186 \\
IC & 92.395 & 77.005 \\
LDR & 0.022 & 64.897 \\
NIM & 0.233 & 45.48 \\
NPL & -0.598 & 24.621 \\
\hline
\end{tabular}

Different from previous studies, intellectual capital negatively affects market risk (NIM). as indicated by the $t$-statistics of $2.047>1.96$ ( $p$-value $0.041<0.05$ ) and the original sample value of -0.217 . Thus, the third hypothesis is empirically supported. In terms of credit risk, the results show that intellectual capital does not affect credit risk, as indicated by the $t$ statistics of $0.254<1.96$ ( $p$-value $0.800>0.05)$ and the original sample value of -0.043 . Thus, the fourth hypothesis is rejected. Similar result also found for operational risk. Operational risk (BOPO) does not have a significant influence on ROA, as indicated by the $t$-statistics value of $0.635<1.96$ ( $p$-value $0.526>$ 0.05 ) and the original sample of -0.098 . Thus, the fifth hypothesis is rejected.

Liquidity risk positively affects banks' financial performance. Our empirical test exhibits significant results, as indicated by the t-statistics value of $2.074>1.96$ ( $p$-value $0.039<0.05)$ and the original sample value of 0.306 . Thus, the sixth hypothesis is empirically supported. Similar findings are found for market risk positively affects banks' financial performance.

The empirical test shows that NIM does not affect ROA as indicated by the $t$-statistics value of $1.234<$ 1.96 ( $p$-value $0.218>0.05$ ) and the original sample value of 0.239 . Consequently, the seventh hypothesis is rejected. Different from previous studies, we document that NPL negatively affects ROA, as indicated by the $t$-statistics value of $3.115>1.96$ ( $p$-value $0.002>$ 0.05 ) and the original sample value of -0.393 . Thus, the eighth is empirically supported. 
However, we find that intellectual capital does not significantly affect ROA, as indicated by the $t$ statistics value of $1.192<1.96$ (p-value $0.234>0.05$ ) and the original sample value 0.191 . Thus, the ninth hypothesis is rejected.

Our empirical test cannot support the last hypothesis, as indicated by the $t$-statistics value of $0.228<1.96$ ( $p$-value $0.819>0.05$ ) and the original sample value of 0.023 . Thus, the tenth hypothesis is rejected.

\section{Discussions}

Our results find the negative impact of intellectual capital and BOPO, as indicated by the variable's $t$ statistics value of 3.219 and the original sample value of -0.334 . Banks' intangible assets likely affect operational risk in the sense that higher intellectual capital reduces BOPO. The findings support Rustiarini and Gama (2012) who find that intellectual capital negatively affects BOPO. In a similar vein, intellectual capital also negatively affects NIM, as indicated by the variable's $t$-statistics of 2.848 and the original sample value of -0.261 . Thus, intellectual capital affects NIM. Specifically, higher intellectual capital reduces NIM. The results are in line with Elfiswandi et al. (2019) who reveal that VACA, VAHU, STVA simultaneously affect NIM (Agustiningrum, 2013). Further, the study empirically observes the positive impact of LDR on ROA, as indicated by the variable's $t$-statistics value of 1.854 and the original sample value of 0.342 . Higher liquidity risk likely affects banks' performance. Banks that distribute more funds to their debtors will generate higher interest revenue and better performance. The findings are in line with Alifah (2014) and Ayuningrum (2011) who demonstrate that LDR positively affects ROA. Further, NPL negatively affects ROA, as indicated by the variable's $t$-statistics value of 3.772 and the original sample value of -0.387 . The findings imply that credit risk is the consequence of banks' failure to have their debtors repay their due loans that affects their ability to generate profits from their assets. The results are in line with Dewi, Herawati, and Sulindawati (2015) who document that NPL negatively affects ROA Our empirical test shows no significant impact of intellectual capital on LDR, as indicated by the variable's $t$-statistics value of 0.766 and the original sample value of 0.080 . The results suggest that intellectual capital cannot reduce liquidity risk.

Intellectual capital, as banks' added values to achieve competitive advantages, cannot mitigate banks' inability to meet short-term or due obligations.
Further, intellectual capital does not significantly affect NPL, as indicated by the variable's $t$-statistics of 1.078 and the original sample value of -0.152 . Thus, higher intellectual capital cannot reduce credit risk. Intellectual capital, as banks' added values to achieve competitive advantages, does not affect the ability of banks' debtors to repay their due obligations to banks. The results are not in line with Aprilina (2013) who reveals that intellectual capital affects LDR and NPL. In a similar vein, BOPO does not significantly affect ROA, as indicated by the variable's $t$-statistics value of 1.108 and the original sample value of -0.195 Thus, operational risk as an internal risk does not affect banks' effectiveness in generating profits from their assets. The findings are not in line with Mismiwati (2016) and Harun (2016) who demonstrate the negative impact of BOPO and ROA. NIM also does not significantly affect ROA, as indicated by the variable's $t$-statistics variable of 1.081 and the original sample value of 0.264 . Higher market risk that is affected by external factors such as interest rate, inflation rate, and recession does not affect banks' effectiveness in generating profits using their assets. The results are in line with Mismiwati (2016) and Harun (2016) who find that NIM does not significantly affect ROA.

Next, intellectual capital does not significantly affect ROA, as indicated by the variable's $t$-statistics of 0.311 and the original sample value of 0.053 . Thus, higher intellectual capital as banks' intangible assets does not affect banks' effectiveness in generating profits from their assets. Our study is in line with Wahdikorin (2010) and Subagyo and Lahagu (2013) who observe that intellectual capital does not significantly affect ROA. Lastly, we do not find the indirect impact of intellectual capital on ROA with banks' risks as the intervening variable, as indicated by the variable's $t$-statistics of 0.384 and the original sample value of -0.035 .

\section{Conclusions and Implications}

The results demonstrate that intellectual capital directly affects operational and market risks. Further, credit risk and liquidity risk affects banks' financial performance. However, intellectual capital does not affect credit risk, liquidity risk, and banks' financial performance. Market risk and operational risk also do not affect banks' financial performance. Even after including banks' risks as the intervening variable, we still find that intellectual capital does not affect banks' financial performance. The Importance-Performance Matrix Analysis (IPMA) shows that our variables 
exhibit positive and negative importance and high and low performance. In this respect, intellectual capital's main components (VACA, VAHU, and STVA) exhibit high importance and performance levels relative to other variables. The variable with a negative importance level is credit risk, indicating that this variable is important but with the negative value. Lastly, the variables with the lowest importance level are liquidity risk (positive value) and operational risk (negative value), while credit risk is the variable with the lowest performance. Our results suggest some implications: theoretical, practical and managerial. The theoretical implications of this study is providing the empirical evidence on the role of banks' risk as the intervening variable in the relationship of intellectual capital and banks' performance. The practical implication of this study is the importance of considering intellectual capital and banks' risk in formulating policy regarding banks' performance.

Lastly, the managerial contribution of this study is that banks need to maintain high intellectual capital, as suggested by the IPMA results that indicate that intellectual capital exhibits high importance and performance. Consequently, banks likely minimize operational and market risks. Besides, banks need to keep their credit and liquidity risks at bay to facilitate higher intellectual capital to improve banks' performance. This study still used a very general liquidity risk variable and had the IPMA value with low importance and performance. We then advise further studies to use other proxies of liquidity risk such as quick ratio. Besides, we suggest future studies to pay more attention to the IPMA values to analyze the importance and performance of the independent variables.

\section{References}

Agustiningrum, R. (2013). Analisis pengaruh car, npl, dan ldr terhadap profitabilitas pada perusahaan perbankan. E-Jurnal Program Studi Manajemen, 2(8), 885-890.

Alifah, Y. B. (2014). Pengaruh car, npl, bopo dan ldr pada perusahaan perbankan yang terdaftar di Bursa Efek Indonesia periode 2009-2012. Unpublished thesis, Universitas Negeri Yogyakarta

Andriana, D. (2014). Pengaruh intellectual capital terhadap kinerja keuangan perusahaan. Jurnal Riset Akuntansi dan Keuangan, 2(1), 251-260. https: //doi.org/10.17509/jrak.v2i1.6578

Aprilina, V. (2013). Pengaruh modal intelektual terhadap kinerja keuangan perbankan di Indonesia. JRAK, 4(2), 14-30.
Attar, D., Islahuddin, \& Shabri, M. (2014). Pengaruh penerapan manajemen risiko terhadap kinerja keuangan perbankan yang terdaftar di Bursa Efek Indonesia. Jurnal Akuntansi, 3(1), 10-20.

Ayuningrum, A. P. (2011). Analisis pengaruh car, $n p l$, bopo, nim dan ldr terhadap roa. Unpublished Thesis, Universitas Diponegoro.

Brunold, J., \& Durst S. (2012). Intellectual capital risks and job rotation. Journal of Intellectual Capital, 13(2), 178-195. https://doi.org/10.1108/1469193 1211225021

Capriani, N. W. W., \& Dana, I. M. (2016). Pengaruh risiko kredit risiko operasional dan risiko likuiditas terhadap profitabilitas BPR di kota Denpasar. E-Journal Manajemen, 5(3), 1486-1512.

Dendawijaya, L. (2009). Manajemen Perbankan. Jakarta: Ghalia Indonesia.

Dewi, L, E., Herawati N. T., \& Sulindawati, N. L. G. E (2015). Analisis pengaruh nim, bopo, ldr dan npl terhadap profitabilitas (Studi kasus pada bank swasta nasional yang terdaftar pada Bursa Efek Indonesia Periode 2009-2013). Journal Ilmiah Mahasiswa Akuntansi Undiksha, 3(1), 1-11.

Dewi, P. A. R., Sedana, I. B. P., \& Artini, L. G. S. (2016). Pengaruh tingkat suku bunga, risiko pasar, debt to equity ratio dan price earning ratio terhadap return saham pada perusahaan properti dan real estate di Bursa Efek Indonesia. E-Journal Ekonomi dan Bisnis Universitas Udayana, 5(3), 489-516.

Elfiswandi, Pratiwi, H., \& Melmusi Z. (2019). The influence of intellectual capital on financial performance: A study on banking companies listed in Indonesia Stock Exchange. Review of Integrative Business and Economics Research, 8(2), 300-311.

Faza, M. F., \& Hidayah E. (2014). Pengaruh intellectual capital terhadap profitabilitas, produktivitas, dan nilai perusahaan pada perusahaan perbankan yang terdaftar di Bursa Efek Indonesia (BEI). Jurnal Ekonomi dan Bisnis Islam, 8(2), 186-199.

Gama, A. W. S., \& Mitariani N. W. E. (2014). Modal intelektual terhadap efisiensi dan kinerja pasar perbankan di Indonesia. Finance and Banking Journal, 16(1), 77-86.

Ghozali, I. (2011). Aplikasi analisis Multivariate dengan program SPSS. Semarang: Badan Penerbit Universitas Diponegoro.

Hair, J. F., Hult, G. T. M., Ringle, C. M., \& Sarstedt, M. (2017). A primer on partial least squares structural equation modeling. $2^{\text {nd }}$ Ed. Thousand Oaks, California: Sage. 
Hariemufti, Y., Kristanti, F. T., \& Mahardika, D. P. K. (2016). Analisis pengaruh risiko kredit, risiko likuiditas, dan permodalan terhadap profitabilitas perbankan, E-Proceeding of Management, 3(2), $1634-1640$.

Harun, U. (2016). Pengaruh rasio-rasio keuangan car, ldr, nim, bopo, npl terhadap roa. Jurnal Riset Bisnis dan Manajemen, 4(1), 67-82.

Haryati R., \& Widyarti E. T. (2016). Pengaruh leverage, size, npl, bopo dan ldr terhadap kinerja keuangan bank (Studi pada bank umum konvensional yang terdaftar di Bursa Efek Indonesia Periode 2010-2014. Diponegoro Journal of Management,5(3), 1-13.

Herdyanto, I., \& Nasir M. (2013). Pengaruh intellectual capital pada financial performance perusahaan. Diponegoro Journal of Accounting, 2(3), 110.

Iqbal, A. (2012). Liquidity risk management: A comparative study between conventional and Islamic banks of Pakistan. Global Journal of Management and Business Research, 12(5), 55-64

Joshi, M., Cahill, D., Sidhu, J., \& Kansal, M. (2013). Intellectual capital and financial performance: An evaluation of the Australian financial sector. Journal of Intellectual Capital, 14(2), 264 -285. https://dx.doi.org/10.1108/14 691931311323887

Jumingan. (2014). Analisis laporan keuangan. Jakarta: Bumi Aksara.

Kansil, D., Murni S., \& Tulung J. E. (2017). Pengaruh resiko perbankan terhadap kinerja keuangan tahun 2013-2015 (Bank Pembangunan Daerah se-Indonesia). Jurnal Emba, 5(3), 3508-3517.

Kuspinta, T. D., \& Husaini A. (2018). Pengaruh intellectual capital terhadap profitabilitas perusahaan. Jurnal Administrasi Bisnis, 56(1), 164 170.

Mismiwati. (2016). Pengaruh car, nim, bopo, ldr dan npl terhadap roa. I-Finance: A Research Journal on Islamic Finance, 2(1), 55-74.

Mondal, A., \& Ghosh, S. K. (2012). Intellectual capital and financial performance of Indian banks. Journal of Intellectual Capital, 13(4), 515-530. Ht tps://doi.org/10.1108/146919312112 76115

Mustofa, M. I., \& Haryanto, A. M. (2014). Analisis pengaruh risiko, tingkat efisiensi, dan good corporate governance terhadap kinerja keuangan perbankan (Pendekatan beberapa komponen metode risk based bank rating SEBI 13/24/dpnp/ 2011). Jurnal Studi Manajemen \& Organisasi, 11 (2), 126-142. https://doi.org/10.14710/jsmo. v 11i2. 13168

Natalia, P. (2015). Analisis pengaruh risiko kredit, risiko pasar, efisiensi operasi, modal, dan likuiditas terhadap kinerja keuangan perbankan.
Jurnal Ekonomi, Manajemen, dan Perbankan, 1(2), 62-73. http://dx.doi.org/10.35384/jemp.vli 2.37

Nijhawan, I. P., \& Taylor, U. (2005). Predicting a Bank's Failure: A case study of a minority bank. Journal of the International Academy for Case Studies, 11 (3), 55-60.

Nurhayati, S. (2017). Analisa pengaruh intellectual capital terhadap kinerja pasar dan kinerja keuangan pada perusahaan LQ45 yang terdaftar di Bursa Efek Indonesia periode tahun 20102013. Jurnal Akuntansi Riset, 9(1), 133-172 https://doi.org/10.17509/jaset.v9i1.5260

Pandia, F. (2012). Manajemen dana dan kesehatan bank. Jakarta: Rineka Cipta.

Pinasti, W. F., \& Mustikawati, R. R. I. (2018). Pengaruh car, bopo, npl, nim dan ldr terhadap profitabilitas bank umum periode 2011-2015. Jurnal Nominal,7(1), 126-142. https://doi.or g/10.21831/nominal.v7 i1.19365

Prahesti, D. S., \& Abundanti, N. (2015). Pengaruh risiko kredit, struktur kepemilikan dan dewan komisaris independen terhadap kinerja keuangan pada industri perbankan di Bursa Efek Indonesia. E-jurnal Manajemen, 4(2), 457-481.

Pratiwi, N. (2014). Pengaruh risiko usaha terhadap skor kesehatan bank umum go public di Indonesia, Journal of Business and Banking, 4(2), 201-216. http://dx.doi.org/10.14414/jbb.v4i2.372

Pulic, A. (2000). Mva and vaic analysis of randomly selected companies from FTSE 250. Austria: Austrian Intellectual Capital Research Center.

Purnomo, E., Sriwidodo, U., \& Wibowo, E. (2018). Pengaruh rasio keuangan terhadap kinerja keuangan pada bank umum swasta nasional devisa yang terdaftar di Bursa Efek Indonesia Periode 2013-2015. Jurnal Ekonomi dan Kewirausahaan, 18(3), 189-198.

Putriani, F. D. (2010). Pengaruh struktur kepemilikan, tingkat keuntungan, risiko perusahaan terhadap kinerja intellectual capital. Unpublished Thesis. Universitas Diponegoro.

Rachmawati, D. A. D. (2012). Pengaruh intellectual capital terhadap return on asset (roa) perbankan. Jurnal Akuntansi, 1(5), 35-37.

Riyadi, S. (2006). Banking assets and liability management. Edisi Ketiga. Jakarta: Lembaga Penerbitan Fakultas Ekonomi Universitas Indonesia.

Robiyanto, R. (2017). Performance evaluation and risk aversion rate for several stock indices in Indonesia Stock Exchange. Jurnal Manajemen dan Kewirausahaan, 19(1), 60-64.

Rustiarini, N. W., \& Gama. A. W. S (2012). Modal intelektual dan kinerja perusahaan: Strategi menghadapi ASEAN Economic Community. Presented in Seminar Nasional Unisbank. 
Sawarjuwono, T., \& Kadir. A. P. (2003). Intellectual capital: Perlakuan, pengukuran, dan pelaporan. Jurnal Akuntansi dan Keuangan, 5(1), 35-57. https://doi.org/10.9744/jak.5.1.pp.\%2035-57

Sholihin, M. \& Ratmono. D. (2013). Analisis sem-pls dengan warp pls 3.0 untuk hubungan nonlinier dalam penelitian sosial dan bisnis. Yogyakarta: Penerbit Andi.

Silaban, S. T. P. (2018). Risk profile, good corporate governance, dan financial performance. Unpublished Thesis. Universitas Kristen Satya Wacana.

Simarmata, R., \& Subowo. (2016). Pengaruh intellectul capital terhadap kinerja keuangan dan nilai perusahaan perbankan Indonesia. Accounting Analysis Journal, 5(1), 1-9. https://doi.org/10. 15294/aaj.v5i1.9748.

Stulz, R. M. (2013). How companies can use hedging to create shareholder value. Journal of Applied Corporate Finance, 25(4), 21-29. https://doi.org/ 10.1111/jacf.12038. (2015). Risk-taking and risk management by banks. Journal of Applied Corporate Finance, 27(1), 8-18. https ://doi.org/10. 1111/jacf.12099

Subagyo \& Lahagu S. H. (2013). Value added intellectual capital (Vahu, vaca, stva) pengaruhnya terhadap kinerja keuangan bank pemerintah periode 2007-2011. Jurnal Akuntansi, 13(1), 833-862.
Sudirman, I. W. (2013). Manajemen perbankan menuju bankir kovensional yang profesional. Edisi Pertama. Jakarta: Kencana Prenada Media Group.

Sugiyono. (2013). Metode penelitian kombinasi (Mixed Methods). Bandung: Alfabeta.

Taswan. (2015). Akuntansi perbankan: Transaksi dalam valuta Rupiah. Edisi III Cetakan 4. Yogyakarta: STIM YPKN.

Thaib, F. (2013). Value added intellectual capital (Vahu, vaca, stva) pengaruhnya terhadap kinerja keuangan bank pemerintah periode 2007-2011. Jurnal Emba, 1(3), 151-159.

Van der Meer-Kooistra, J., \& Zijstra S. M. (2001). Reporting on intellectual capital. Accounting, Auditing, \& Accountability Journal, 14(4), 456476. https://doi.org/10.1108/095135 70110403461

Wahdikorin, A. (2010). Pengaruh modal intelektual terhadap kinerja keuangan perusahaan perbankan yang terdaftar di Bursa Efek Indonesia. Unpublished Thesis. Universitas Diponegoro.

Yalama, A. (2013). The relationship between intellectual capital and banking performance in Turkey: Evidence from panel data. International Journal of Learning and Intellectual Capital, 10(1), 71-87. https://doi.org/10.1504/IJLIC. 2013.052079. 


\section{Attachment 1}

Operational Definition, Empirical Indicators, and Variable Measurements

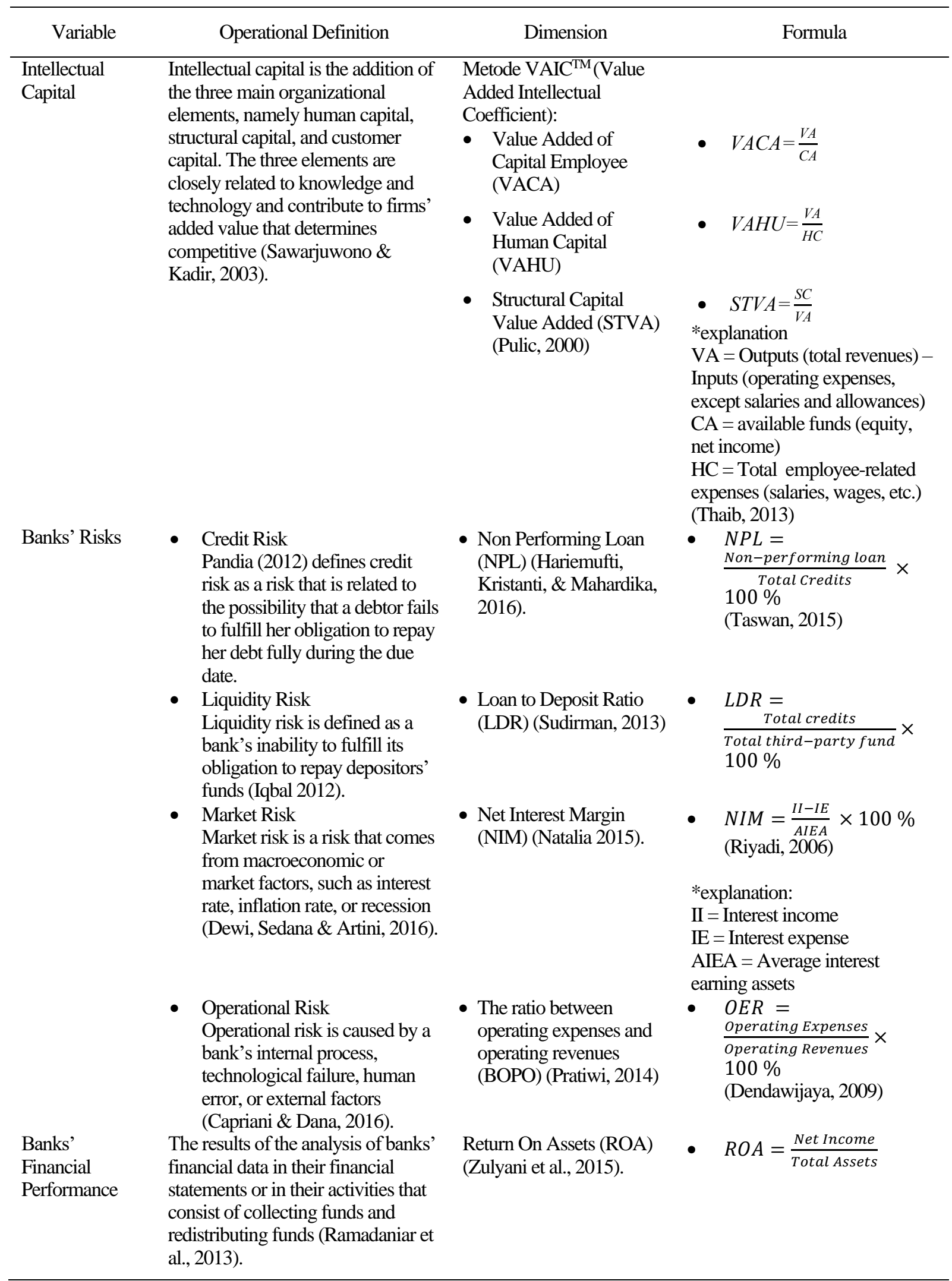

